the former. Fossiliferous Permian marls discovered in the south of the area are of economie importance in regard to the exploration of the coalfield concealed beneath them. Special chapters deal with this topic, and with the palæontology of the Coal Measures, the economic products, and the glacial geology.

\section{Reports on Mineral Resources}

The report on gypsum, anhydrite, celestine and strontianite $^{\theta}$ is now in its third edition. Since the second edition appeared in 1917, anhydrite, which was then a waste product, has become a valuable raw material in the manufacture of ammonium sulphate and sulphuric acid. The gypsum industry has greatly expanded as a result of the development of gypsum plasters and cement. Celestine and strontianite are the only sources of strontium compounds. These are used in the beet-sugar industry, as fillers in special paints and gramophone records, and for red flares in pyrotechny. The report gives details of the geology, mode of occurrence and distribution, mining and quarrying, uses and treatment, and reserves and statistics of these four minerals.

The report on the "Granites of Scotland"10 brings together in compact form accounts of the distribution, mode of occurrence and leading characteristics of the principal Scottish granites, intended primarily for the use of those engaged in the granite industry. The first three chapters deal in succession with the development of the industry, with the mineralogical, chemical and physical properties of granite, and with the distribution and age-relationships of the occurrences. Later chapters provide details of the granites of north-east Scotland, of the Galloway district in the south-west, and of the Western Highlands. These include all the most important centres. Special attention is given to granites at present being wrought, and an account is given of the methods of working in active use. Other occurrences of granite throughout Scotland are also briefly described. A list of the quarries in operation during 1938 is appended.

1 "Summary of Progress of the Geological Survey of Great Britain and the Museum of Practical Geology for the Year 1936". Part I. Pp. viil +90. 1936. 18. 6d. net.

2 "Summary of Progress". Part II. Pp. viii $+83+1$ plate. 1938. 1s. $6 d$. net.

s "Summary of Progress of the Geological Survey of Great Britain and the Museum of Practical Geology for the Year 1937." Pp. viii +109 . 1938. 2s. net.

- Bulletin of the Geological Survey of Great Britain, No. 1. Pp. xi+ $108+7$ plates. 1939 . 28. $6 d$. net.

${ }^{5}$ Bulletin, No. 2. Pp. $x i+96+6$ plates. 1939. 2s. net.

" "The Economic Geology of the Central Coalfield: Area I (Kilsyth and Kirkintilloch)." By T. Robertson and $\dot{D}$. Haldane. Pp. viii $+169+2$ plates. 1937 . $3 s$. $6 d$. net.

7 "Shrewsbury District, including the Hanwood Coalfield (One-inch Geological Sheet 152, New Series)." By R. W. Pocock, T. H. Whitehead, C. B. Wedd and T. Robertson, with contributions by D. A. Wray, C. J. Shibblefleld, T. C. Cantrill and W. M. Davies. Pp. xxi $+297+8$ plates. 1938 . 5s, net.

"Wigan District (One-inch Geological Sheet 84, New Series)." By R. C. B. Jones, L. H. Tonks and W. B. Wright. Pp. xvi $+244+9$ R. C. B. Jones, L. H. Ton
plates. 1938 . 5 s. net.

- Special Reports on the Mineral Resources of Great Britain. 3, "Gypsum and Anhydrite", by R. L. Sherlock and B. Smith. and "Celestine and Strontianite", by R. L. Sherlock. Third edition by R. L. Sherlock and S. E. Hollingworth. Pp. $\mathrm{x}+98$ 1938. $28.6 d$. net.

10 Special Reports on the Mineral Resources of Great Britain, 32, "The Granites of Scotland", by J. G. C. Anderson, with a contriMacgregor. Pp $70+4$ plates, 1939, 28, 6d, net. London: H.M. Stationery Office.

\title{
RADIO FREQUENCY WAVE GUIDES
}

$\mathrm{W}$ ITH the continuous extension of radio research to increasingly higher frequencies, it is not surprising to find occasionally that radical changes in technique and equipment occur. Such changes are already envisaged in the practical application of decimetre and centimetre electric waves, that is, the wave-length band from $1 \mathrm{~cm}$. to $100 \mathrm{~cm}$. So long ago as 1897, Lord Rayleigh gave a mathematical analysis of the propagation of electric waves along hollow tubes of either circular or rectangular crosssection, and showed that this type of transmission could take place only when the wave-length was of the same order as, or less than, the cross-sectional dimensions of the tube. Consequently this subject attracted little attention until about 1935, when suitable methods of generating these very high frequencies had been developed. Since this date the matter has been investigated in some detail in the United States, notably in the Bell Telephone Laboratories and the Massachusetts Institute of Technology, and also to a lesser extent in France and Germany.

A good review of the investigations conducted in the past few years was given by Dr. J. E. Houldin in a paper read on February 19 before the London Students' Section of the Institution of Electrical Engineers. It has been shown by analysis and verified experimentally that several types of waves can exist within the tube, but particular attention has been devoted to four of these. As is to be expected, there is a critical free-space wave-length above which no transmission along the tube takes place. Tubes having diameters of the order of $10 \mathrm{~cm}$. appear to be practically convenient for use in the wave-length band $10-30 \mathrm{~cm}$. By filling a copper or bakelite tube with water, the effective wave-length in the tube is reduced, with certain practical advantages for experimental work.

The velocity of propagation and attenuation of the waves depend upon the type of wave used, the wavelength and cross-sectional dimensions of the tube and the nature of the dielectric with which the tube is filled. It has been shown that at wave-lengths of $10 \mathrm{~cm}$. and below, the hollow metal tube has an attenuation per unit length smaller than that of a co-axial cable of zero dielectric loss and the same external diameter. Owing to the omission of the central conductor and its dielectric supports, the hollow metal tube is simpler and cheaper to construct.

If an open-ended metal tube be excited with oscillations of suitable wave-length, the waves travel towards the open end and are radiated into space. Such radiation may be either vertically or horizontally polarized, or a combination of these, depending upon the type of waves set up in the tube. This radiation is transmitted predominantly forward, and by the use of a suitable flared. horn on the open end of the tube, a well-defined beam is obtainable.

Experiments with various horns and tubes have shown that the gain of energy transmitted in the desired direction over that given by an omnidirectional radiation is comparable with that obtained in the practical use of antenna arrays on the wavelengths of 10-100 metres used in the beam system of short-wave communication. $\quad$ R. L. S-R. 